\title{
LIFELONG LEARNING AND E-LEARING AWARENESS: THE CASE STUDY OF INTERNATIONAL COLLEGE STUDENTS AT SUAN SUNANDHA RAJABHAT UNIVERSITY
}

\author{
Phinyar Chaisongkram \\ Suan Sunandha Rajabhat University, Bangkok, Thailand
}

Lifelong learning is one of the most important skills in the 21st century. The main purpose of lifelong learning is active citizenship which is important in terms of connecting individuals to the structures of social and economic activity in both local and global contexts. Lifelong learning is high on the agenda in the education sector around the world. It has been an important part of many education policies and part of Thailand's National Education Act since 2012. Skills' development for lifelong learning has been emphasized within the 11th National Economic and Social Development Plan (B.E 2555-2559). Online learning included MOOC (Massive Open Online Courses) such as edX, Coursera and other online course platforms such as Khan Academy, Udemy, etc. These all are efficient, time-effective and costeffective tools supporting lifelong learning. Many research studies have already provided recommendations on how to accelerate the implementation of lifelong learning supported by online learning.

The purpose of this study is to investigate higher education student awareness about lifelong learning and online learning. Universities need to take responsibility for preparing students for lifelong learning. Thus, the participants in this study were the students at International College, Suan Sunandha Rajabhat University (Bangkok, Thailand); they were selected through random sampling. This study has applied quantitative research methods, namely, an online survey to collect data. The results of this study can be used to improve lifelong learning skills among university students in other countries as well.

Keywords: lifelong learning; e-learning; online learning; online course; student survey

\section{Introduction}

Lifelong learning is becoming an important skill for all careers. Lifelong learning is the ability to continuously expand one's own mind and knowledge. In 2015, the World Economic Forum (WEF) published a report titled "New Vision for Education: Unlocking the Potential of Technology". This report focused on the 21 st-century skills, a set of 16 crucial proficiencies for education in this century. Those 16 skills can be obtained and improved by

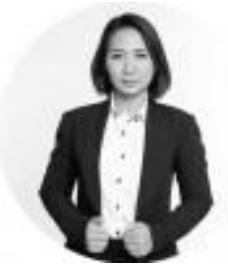

\section{Phinyar Chaisongkram}

Lecturer in International College Suan Sunandha Rajabhat University, program of Digital International Business, Bangkok, Thailand

Research interests: digital marketing, digital entrepreneurship, e-sport, e-commerce Published more than 15 research papers in international journals and students manuals.

E-mail: phinyar.ch@ssru.ac.th 
having lifelong learning skills. Lifelong learning is a continuous process in which individuals retain and develop their life-based conduct, knowledge and skills. The main aim of lifelong learning is to reinforce and improve the life quality of individuals by enabling them to bring their own potential to the utmost level. Lifelong learning is also defined as "all learning activities undertaken throughout life, with the aim of improving knowledge, skills and competences within a personal, civic, social and/or employment-related perspective". Rapid popularization of the Internet and all related technologies is an important part for lifelong learning.

In October 2011, Stanford professors launched three free online courses; open to the general public and all interested students around the world (Commission of the European Communities, 2011). More than 100,000 students enrolled on those three courses then. "Coursera", an online learning platform, was launched in April 2012. One month later, Massachusetts Institute of Technology and Harvard University launched edX. At present, there are more than 12,000 MOOC providers around the world. Many national governments have launched their own, country-specific MOOC platforms, including India, Mexico, Italy, Israel and Thailand (in the latter case it would be ThaiMooc.org). Apart from MOOC, there is a number of other online course marketplaces, both worldwide platforms such as Udemy, Skillshare, Skill Success, Coggno, SkillWise and also more local platforms such as SkillLane. The number of enrollers on MOOC and other online courses is increasing rapidly and continuously (Shah \& Pickard, 2019). The number of students enrolled on MOOCs around the world back in 2018 increased by 188\% (as compared to 2015), from $35 \mathrm{mln}$ students in 2015 to $101 \mathrm{mln}$ students in 2018.

Overall, there is a growing number of online learning resources, both in Thailand and around the world. This research aims to study the level awareness about lifelong learning and online learning among the undergraduate students at the International College, Suan Sunandha Rajabhat University. If the level of their awareness is high, online learning would benefit. Then we should develop more online courses to serve the students. On the other hand, if the level of their awareness is low, we might have to develop lifelong learning and online learning awareness among them before developing more online courses. Therefore, we came up with the following research questions:

(1) Are students aware of online learning resources as such?

(2) Do students use the already available online learning resources?

(3) Is there any significant difference between college years and use the online learning resources?

(4) Why don't students use the online learning resources?

\section{Literature review}

\section{E-learning and online learning}

Nowadays, the Internet offers various options to learn whatever we want. Most people might think online learning and e-learning have the same meaning but actually it is not the same. E-learning is the process of providing courses on the Internet or intranet.

E-learning includes applications, programs, objects, websites that can eventually provide learning opportunities for individuals (Moore ey al., 2011). E-learning course uses an e-learning platform (LMS) with a set number of functions and a specific structure designed for interaction with lecturers. Some important characteristics of e-learning include: closed 


\section{LIFELONG LEARNING AND E-LEARING AWARENESS}

environment, limited groups, evaluation and accreditation oriented, offered at very specific moments of an academic year.

Online learning is a much broader notion (Laal, 2011). The main element of online learning is to get learning experience by using Internet connection. Massive Online Open Course (MOOC) is one of the most famous online learning tools at present. Millions of students from around the globe have enrolled on MOOCs; thousands of courses have been offered; hundreds of universities have lined up to participate (Christensen et al., 2013). Education in the 21 st century is rapidly moving towards autonomous learning, fullyintegrated LMSs (thus to wider e-learning) or MOOCs are becoming the new standard in education.

\section{Online Learning Resources}

Various online learning resources are available for us to learn. They can be free and paid ones, private (close) and public (open), self-paced and instructor-paced. Hundreds of online learning resources have been launched during the past decade. Online learning resources can be divided into four main categories:

- Video Hosting Services: These are platforms which allow users to upload, share videos and/or live stream their own videos to the Internet. These can either be for general public to watch, or for specific users only who are sharing a closed network. The most popular video hosting website is YouTube, with its 1.8 bln logged-in users per month and the most extensive catalog of online videos (Gilbert, 2018). Other examples of such hosting services include: Vimeo, Dailymotion, Tune, SchoolTube, LiveLeak, Mixer, etc.

- Online Course Platform (Online Course Marketplace): These are platforms/marketplaces for the professionals with specific skills, including teachers. Here they can create and offer online courses which can be both free and paid ones. The examples of such online course platforms are Udemy, Skillshare, Teachable, Eliademy, Podia, Thinkific, Learnworlds, Khan Academy, etc (Mouzakitis \& Tuncay, 2011).

- Massive Online Open Course (MOOC): This is an online course aimed at unlimited participation, with open access via the web. In addition to traditional course materials, such as filmed lectures, readings, and problem sets, many MOOCs provide interactive courses with user forums to support community interactions among students, professors, and teaching assistants (TAs) and also in order to get immediate feedback. The examples of MOOC are Coursera (USA), edX (USA), FutureLearn (UK), SWAYAM (India), XuetangX (China), Udacity (USA), Miríadax (Spain), thaiMOOC (Thailand), etc.

- Other: Other online learning resources which are not video hosting services, online course platforms and MOOC should be considered as a special category. Here belong, for example, Quora.com, an American question-and-answer website where questions are asked, answered, and may be also edited by the Internet users, either factually, or in the form of opinions.

\section{Online learning in Thailand}

Rapid growth of the Internet and various related technologies has enabled successful implementation of online learning around the world, including Thailand. Thai universities pay serious attention to developing e-learning and online courses. In 2017, Thailand Cyber University (TCU), an organization responsible for providing extra educational opportunities for Thai people, started a project titled "Thai MOOC: Lifelong learning space for all". 
Thai MOOC has 228,383 users now and is providing more than 400 courses from 95 institutions (as of $2^{\text {nd }}$ September 2019). Apart from Thai MOOC, there is a number of online learning resources from various universities and institutions. Table 1 below shows several examples of such online learning resources available in Thailand.

Table 1 - Online learning resources in Thailand

(Source: data of Thailand Ministry of education and science)

\begin{tabular}{|c|c|c|c|}
\hline Website & Owner & Category & $\begin{array}{c}\text { Number of } \\
\text { courses }\end{array}$ \\
\hline Thai MOOC & Thailand Cyber University & MOOC & $>400$ \\
\hline Chula MOOC & Chulalongkorn University & MOOC & $<50$ \\
\hline Space by CBS & Chulalongkorn University & MOOC & 15 \\
\hline MUX & Mahidol University & MOOC & $>500$ \\
\hline Skilllane & Skilllane Education Co., Ltd. & $\begin{array}{c}\text { Online Course } \\
\text { Platform }\end{array}$ & $>1,000$ \\
\hline Edumall & Topica Edtech Group & $\begin{array}{c}\text { Online Course } \\
\text { Platform }\end{array}$ & $>1,000$ \\
\hline Thailand & & \multicolumn{2}{|c|}{} \\
\hline
\end{tabular}

\section{Methodology}

Quantitative research method has been applied in this research. The research approach of this study is descriptive survey.

The objective of this research is to determine the awareness concerning lifelong learning and online learning among the International College students of Suan Sunandha Rajabhat University. The population of the study has been 770 , which is the total population of Suan Sunandha Rajabhat University, International College students. The sample size was 163 (confidence level - 95\% and the margin of error - 8\%). The sample has been selected by means of simple random sampling. Participants of this study are all undergraduate students of the College in question which means they have been studying at the university for the last 1-3 years.

Online questionnaire was used as the research instrument. The descriptive statistics were analyzed using frequency counts and percentages. The questionnaire was titled "SSRUIC Lifelong Learning and Online Learning Awareness Survey". The headline of this questionnaire informed the participants that this questionnaire would be further used for the research on lifelong learning and online learning awareness and also that participation in this research has been voluntary.

\section{Analysis of the Findings}

Out of the 164 respondents in total, 67 (or 41\%) were first-year students and 69 (or $42 \%$ ) were second-year students, finally 28 respondents (or 17\%) were third-year students. The descriptive statistics is presented in Tab. 2 and 3. 


\section{LIFELONG LEARNING AND E-LEARING AWARENESS}

Table 2 - Awareness about online learning resources

(made by the author)

\begin{tabular}{|l|c|c|c|c|}
\hline \multicolumn{1}{|c|}{ College Year } & Aware & $\%$ & Not Aware & $\%$ \\
\hline First year & 12 & 17.9 & 55 & 82.1 \\
\hline Second year & 13 & 18.8 & 56 & 81.2 \\
\hline Third year & 9 & 32.1 & 19 & 67.9 \\
\hline Total & 34 & 20.7 & 130 & 79.3 \\
\hline
\end{tabular}

Table 3 - Use of online learning resources

(made by the author)

\begin{tabular}{|c|c|c|c|c|}
\hline College Year & Used & $\%$ & Not Used & $\%$ \\
\hline First year & 17 & 25.4 & 50 & 74.6 \\
\hline Second year & 6 & 8.7 & 63 & 91.3 \\
\hline Third year & 4 & 14.3 & 24 & 85.7 \\
\hline Total & 31 & 18.9 & 133 & 81.1 \\
\hline
\end{tabular}

The results presented in Tab. 2 and 3 demonstrate that the awareness about online learning resources is very low and also that the actual usage of online learning opportunities is very low. Only $34(20.7 \%)$ of our respondents are aware of online learning resources and then only $31(18.9 \%)$ had actual experience with using online learning resources. The highest level of awareness has been demonstrated by the third-year students (32.1\%), same applies to the use of online learning resources by the first-year students (25.4\%).

The third part of our questionnaire reveals information on the experience of using online learning resources by the College students. Most of the surveyed students who have some experience of using online learning resources $(90.3 \%)$ used online learning resources to learn something that is directly related to some subject in their school or college. Only $9.7 \%$ of the students with some experience of using online learning resources enrolled on such courses because they were curious to learn something that is directly not related to their subjects in school or college (see Tab. 4).

Table 4. Statistics on taking online course related or not related to some subjects at school or college (made by the author)

\begin{tabular}{|l|c|c|c|c|}
\hline & Related & Percentage & $\begin{array}{c}\text { Not } \\
\text { Related }\end{array}$ & Percentage \\
\hline $\begin{array}{l}\text { Answer: I have taken an online course which is } \\
\text { related/nor related to a subject at school or } \\
\text { college }\end{array}$ & 28 & $90.3 \%$ & 3 & $9.7 \%$ \\
\hline \multicolumn{1}{|c|}{ Total } & \multicolumn{3}{|c|}{31 respondents } \\
\hline
\end{tabular}

The result from the third part of our questionnaire show that most of the respondents are familiar with video-hosting services, especially YouTube (20 respondents, or $64.5 \%$ of 
the students who have experience with using online learning resources). Apart of YouTube, they also have some experience with using English language learning websites such as Angkriz, da'vance, enconcept (5 respondents mentioned them, or $16.1 \%$ of those with experience in using online learning resources). Finally, 6 respondents (or 19.3\%) state they have been using various MOOCs such as Chula MOOC, Coursera, Thai MOOC.

Then we have asked the students who had never been using online learning resources about their potential desire to use online learning resources or take course online in future. The obtained responses are shown in Tab. 5.

$45.1 \%$ of the students, who had never been using online learning resources are considering the use of online learning resources or taking online courses some time in the future (60 respondents). 30.8\% of the students who had never been using online learning resources are willing to use online learning resources or take a course online if they want to know or learn something new. 15 respondents, or $11.3 \%$ of the students, who had never been using online learning resources do not want to use online learning resources or take courses online in future because they are lazy. Finally, one respondent stated that he/she prefers to learn with a teacher/ lecturer rather than be learning by themselves.

Table 5. The desire to use online learning resources or take courses online in future (made by the author)

\begin{tabular}{|l|c|c|}
\hline & $\begin{array}{c}\text { Number of } \\
\text { respondents }\end{array}$ & $\%$ \\
\hline Willingness to use online learning resources or take online courses in the future \\
\hline Maybe, I'm not sure yet & 60 & 45.1 \\
\hline Yes. If I want to know something new, I will & 41 & 30.8 \\
\hline Of course, I want to learn new things & 15 & 11.3 \\
\hline Not willing to use online learning resources or take course online in future \\
\hline No, I am lazy & 16 & 12.0 \\
\hline $\begin{array}{l}\text { Never, I don't want to learn by myself. I always need a } \\
\text { teacher or a lecturer }\end{array}$ & 1 & 0.8 \\
\hline \multicolumn{1}{|c|}{ Total } & 133 respondents \\
\hline
\end{tabular}

\section{Conclusions}

The awareness about lifelong learning and online learning is growing worldwide all the time. The number of online students in Thailand, on MOOCs and other online courses/ marketplaces is still tiny if compared with the number of offline students in Thailand. MOOC is becoming very popular these days and many people are getting huge benefits from it: they are getting high-quality information from experienced instructors and saving costs at the same time; they are learning from anywhere anytime. However, this doesn't automatically mean that MOOC is suitable for everyone absolutely. From this study alone, only $20 \%$ of the SSRUIC students are aware of online learning resources and less than $20 \%$ of these students have some experience with using online learning resources.

In our view, the first thing that has to be done is developing lifelong learning and online learning awareness inside the student community before developing new online 


\section{LIFELONG LEARNING AND E-LEARING AWARENESS}

courses (since no one will be willing to use those. There is an opportunity to develop lifelong learning and online learning awareness within Suan Sunandha Rajabhat University International College students' community because $87.2 \%$ of the surveyed students who had never been using online learning resources are actually willing to use online learning resources and/or take courses online in future. College administration and lecturers should have more activities to create awareness and promote the usage of online learning resources, including video-hosting services, online course platforms and MOOCs.

\section{References}

Christensen, G., Steinmetz, A., Alcorn, B., Bennett, A., Woods, D. \& Emanuel, E. (2013). The MOOC Phenomenon: Who Takes Massive Open Online Courses and Why? SSRN Electronic Journal.

Commission of the European Communities. (2011). Making a European Area of Lifelong Learning a Reality.

Gilbert, B. (2018). YouTube now has over 1.8 billion users every month, within spitting distance of Facebook's 2 billion. Retrieved 10 October 2019, from: https://www.businessinsider.com/youtube-user-statistics-2018-5/

Laal, M. (2011). Lifelong Learning: What does it Mean? Procedia - Social And Behavioral Sciences, $28,470-474$.

Moore, J., Dickson-Deane, C. \& Galyen, K. (2011). e-Learning, online learning, and distance learning environments: Are they the same? The Internet And Higher Education, 14(2), 129-135.

Mouzakitis, G. \& Tuncay, N. (2011). E-Learning and lifelong learning. The Turkish Online Journal of Distance Education, 12.

Shah, D. \& Pickard, L. (2019). Massive List of MOOC Providers Around The World. Retrieved from: https://www.classcentral.com/report/mooc-providers-list/.

World Economic Forum (2015). New Vision for Education Unlocking the Potential of Technology. Retrieved from: http://www3.weforum.org/docs/ WEFUSA_NewVisionforEducation_Report2015.pdf.

Paper submitted

Paper accepted for publishing

Paper published online
09 May 2020

14 July 2020

31 July 2020 